\title{
PENGARUH ADVERTENSI DAN LAYANAN PURNA JUAL TERHADAP KEPUASAN PELANGGAN PADA PT ELECTRONIC CITY CABANG BOGOR
}

\author{
Hasan Basri \\ Dosen Tetap Fakultas Ekonomi Universitas Pakuan
}

\begin{abstract}
ABSTRAK
Penelitian ini bertujuan untuk mengetahui pengaruh advertensi terhadap kepuasan pelanggan, pengaruh layanan purnajual terhadap kepuasan pelanggan, pengaruh advertensi dan layanan purnajual secara bersama-sama terhadap kepuasan pelanggan. Penelitian dilaksanakan dari bulan November 2011 sampai dengan Januari 2012 bertempat di PT Electronic City Bogor. Pengambilan sampel menggunakan metoda random sampling dengan jumlah 130 responden. Kesimpulan dari hasil penelitian adalah sebagai berikut: 1) Terdapat pangaruh positif yang signifkan $(\alpha=0,05)$ dari advertensi terhadap kepuasan pelanggan dengan persamaan regresi $\left.\hat{Y}=72,406+0,347 \mathrm{X}_{1} ; 2\right)$ Terdapat pengaruh positif yang signifkan $(\alpha=0,05)$ dari layanan purnajual terhadap kepuasan pelanggan dengan persamaan $\hat{Y}=67,375+0,365 \mathrm{X}_{2}$; 3) Terdapat pengaruh positif yang signifkan $(\alpha=0,05)$ dari advertensi dan layanan purnajual secara bersama-sama terhadap kepuasan pelanggan dengan persamaan $\hat{Y}=42,871+0,283 X_{1}+0,303 X_{2}$. Implikasi dari hasil penelitian adalah sebagai berikut: 1) Semakin tinggi tingkat advertensi yang disampaikan, maka kepuasan pelanggan akan semakin meningkat; 2) Semakin tinggi tingkat layanan purnajual yang ditawarkan, maka kepuasan pelanggan akan semakin meningkat; dan 3) Semakin tinggi tingkat advertensi dan layanan purnajual secara bersama-sama ditawarkan, maka kepuasan pelanggan semakin meningkat.
\end{abstract}

Kata kunci: Advertensi, layanan purna jual, dan kepuasan pelanggan.

\begin{abstract}
The objective of this research is to find out the effect of advertisement and after-sale service on customer satisfaction at PT Electronic City Bogor. The research was held from November 2011 to Januari 2012. The population is customer of PT Electronic City Bogor, the reachable population is 130 by random sampling. The conclusions from the study are as follows: 1) There is a positive and significant $(\alpha=0.05)$ effect of advertisement on customer satisfaction with regression equation $\hat{Y}=72.406+0.347$ $X_{1}$; 2) There is a positive and significant $(\alpha=0.05)$ effect after sale service on customer satisfaction with regression equation $\hat{Y}=67.375+0.365 X_{2}$, 3) There is a positive and significant $(\alpha=0.05)$ effect of advertisement and after-sale service altogether on customer satisfaction with regression equation $\hat{Y}=$ $42.871+0.283 X_{1}+0.303 X_{2}$. The implications of the research results are as follows: 1) The higher of advertisement offered, will lead to the higher customer satisfaction; 2) The higher the after sale service offered, will lead to the higher customer satisfaction; 3) The higher of advertisement and after-sale service offered altogether, will lead to the higher customer satisfaction.
\end{abstract}

Keywords: Advertisement, after-sale service, and customer satisfaction.

\section{Pendahuluan}

Dunia usaha di Indonesia saat ini telah berkembang dengan pesat seiring dengan keterbukaan ekonomi global. Oleh karena itu, para pelaku usaha tidak dapat lagi menghindari persaingan bisnis yang terjadi. Kondisi seperti ini mendorong para pelaku usaha untuk senantiasa meningkatkan mutu dan kinerja seluruh sumber daya yang dimiliki agar memiliki daya saing yang kuat dan produk atau jasa yang dihasilkan kualitasnya dapat terus menerus ditingkatkan guna memenuhi harapan masyarakat sebagai konsumennya. 
Banyak perusahaan yang sedang bersaing dalam mendapatkan konsumen agar dapat mencapai target pertumbuhan yang diharapkan. Untuk mendapatkan hasil yang maksimal, perusahaan berlomba-lomba memberikan pelayanan yang prima terhadap konsumen. Semakin puas pelayanan yang dirasakan oleh konsumen maka semakin banyak konsumen membeli barang terhadap perusahaan tersebut.

Pada saat ini konsumen membutuhkan suatu kepuasan yang dapat memenuhi kebutuhannya dan tidak perlu lagi susah payah dalam mencari informasi. Dengan terpenuhinya kepuasan tersebut, maka membawa dampak yang positif bagi perusahaan dalam segi pendapatan atau hasil tujuan perusahaan serta membuat citra perusahaannya menjadi maju di mata masyarakat luas. Banyak perusahaan yang maju atau mundur dikarenakan hasil akhirnya tidak bisa tercapai.

Dengan tercapainya kepuasan konsumen, diharapkan akan terbangun loyalitas pelanggan yang pada akhirnya menjadikan promosi berantai (word of mouth). Menjadikan citra perusahaan dimata umum terbawa luas dan sangat dikenal. Di samping itu juga menjadikan suatu persaingan antara sesama perusahaan dengan cara memberikan kepuasan kepada konsumen. Karena hampir semua perusahaan sekarang ini mengutamakan kepuasan konsumen dan memberikan kemudahan apa yang diinginkan atas kebutuhannya.

Konsumen sekarang ini tidak susah payah mencari informasi apa yang diinginkannya. Mulai dari kebutuhan dirinya sendiri, keluarga, maupun yang lainnya seperti untuk perusahaannya sendiri. Banyak perusahaan yang menawarkan jasa yang siap antar ke tempat tujuan konsumen dan tidak perlu membutuhkan waktu yang lama, dibuat secara otomatis guna memenuhi kebutuhan konsumen. Konsumen tersebut bisa menjadikan pelanggan terhadap perusahaan yang memberikan pelayanan yang bisa memenuhi kebutuhannya yang nantinya akan balik terus bahkan konsumen tidak akan pindah ke tempat yang lain jika sudah mempunyai langganan untuk memenuhi kebutuhannya.

PT Electronic City cabang Bogor diketahui pada tahun 2010 ada penurunan penjualan dan ada peningkatan jumlah komplain dari tahun sebelumnya. Selama tahun 2009 jumlah transaksi sebanyak 31.803 dan pada tahun 2010 jumlah transaksi sebanyak 31.420. Hal ini menyebabkan adanya penurunan jumlah transaksi sebanyak 383 (1,2\%). Selama tahun 2009 jumlah komplain sebanyak 2.433 orang. Jumlah tersebut dibagi ke dalam beberapa kategori komplain diantaranya : kualitas produk sebanyak 363 (15\%), pelayanan karyawan sebanyak 168 (7\%), hadiah sebanyak 124 (5\%), pesanan produk sebanyak 299 (12\%), harga sebanyak 140 (6\%), advertensi sebanyak 398 (16\%), pembayaran sebanyak $93(4 \%)$, dan purnajual sebanyak 849 (35\%). Pada tahun 2010 jumlah komplain sebanyak 2.676 orang (10\% kenaikan jumlah komplain). Jumlah tersebut dibagi ke dalam beberapa kategori komplain diantaranya : kualitas produk sebanyak 320 (12\%), pelayanan karyawan sebanyak 144 (5\%), hadiah sebanyak $132(5 \%)$, pesanan produk sebanyak 313 (12\%), harga sebanyak $155(6 \%)$, advertensi sebanyak 471 (18\%), pembayaran sebanyak 106 (4\%), dan purnajual sebanyak 1035 (39\%).

Semakin banyak yang komplain menyebabkan semakin turun konsumen yang membeli produk di perusahaan. Hal ini menyebabkan semakin banyak konsumen yang kurang puas dengan pelayanan PT Electronic City cabang Bogor. Mulai dari informasi promo yang 
masih belum tapat pada sasarannya, tingkat service yang masih ada melebihi dari batas waktu yang ditentukan, pengririman homedelivery yang masih meminta waktu dari konsumen. Semua ini masih banyak konsumen yang mengeluhkannya.

Tujuan umum adalah menguji dan menganalisa variabel advertensi dan layanan purnajual dalam mempengaruhi kepuasan pelanggan. Tujuan khusus: 1) Mengetahui pengaruh advertensi terhadap kepuasan pelanggan; 2) Mengetahui pengaruh layanan purnajual terhadap kepuasan pelanggan; dan 3) Mengetahui pengaruh advertensi dan layanan purnajual secara bersama-sama terhadap kepuasan pelanggan

\section{Landasan Teori}

\subsection{Hakikat Kepuasan Pelanggan}

Di saat persaingan semakin ketat, produsen berusaha memenuhi kebutuhan dan keinginan konsumen dengan menawarkan berbagai jenis produknya. Dampaknya konsumen memiliki banyak pilihan, kekuatan tawar-menawar konsumen semakin besar, yang mendorong setiap perusahaan harus menempatkan orientasinya pada kepuasan pelanggan sebagai tujuan utamanya. Produsen semakin yakin bahwa kunci sukses untuk memenangkan persaingan terletak pada kemampuannya memberikan "total customer value" yang dapat memuaskan pelanggan

Menurut Philip Kotler bahwa kepuasan adalah "Satisfaction is a person's feeling of pleasure or disappointment resulting from comparing a product's perceived performance (of outcome) in relation to his or her expectations". Kepuasan adalah perasaan seseorang senang atau kecewa yang dihasilkan dari membandingkan kinerja produk yang dirasakan (dari hasil) sehubungan dengan harapan nya. Faktor yang mempengaruhi kepuasan pelanggan diantaranya : (a) kebutuhan, Pengalaman pembelian sebelumnya.

Menurut Ali Hasan Kepuasan pelanggan merupakan fungsi dasar dari sejumlah nilai produk (kinerja) yang dipersepsikan oleh pelanggan dibanding dengan harapan pelanggan sebelum menggunakan. Rumusan ini dapat diformulasikan sebagai berikut: Kepuasan $=\mathrm{f}$ (Harapan terhadap produk : Kinerja produk yang dirasakan). Faktor-faktor yang mempengaruhi kepuasan pelanggan diantaranya adalah (a) Kebutuhan pribadi, (b) Pengalaman masa lampau, (c) Rekomendasi dari mulut ke mulut, (d) Iklan.

Berdasrkan teori-teori di atas penulis dapat menyimpulkan bahwa Kepuasan pelanggan adalah perasaan yang timbul pada konsumen dalam bentuk senang atau kecewa yang berawal dari sebuah transaksi. Adapun faktorfaktor yang mempengaruhi terhadap kepuasan pelanggan adalah kebutuhan pribadi, pengalaman masa lampau, kesesuaian dengan spesifikasi, dan kualitas produk.

\subsection{Hakikat Advertensi}

Advertensi adalah alat penjualan yang mempunyai pengertian yang sama dengan iklan. Menurut Philip Kotler bahwa "advertising is formally defined as any paid form of nonpersonal presentation and promotion of ideas, goods, or services by an identified sponsor". Advertensi secara formal didefinisikan sebagai bentuk media yang dibayar nonpersonal dalam bentuk presentasi dan promosi dari ide-ide, barang atau layanan yang diidentifikasi oleh sponsor. Faktor-faktor yang mempengaruhinya diantaranya : (a) Public relation (humas), (b) Direct marketing (pemasaran langsung), (c) Special promotion items (Promo barang- 
barang khusus), (d) Communication channels (saluran komunikasi).

Menurut William G. Zikmund dan michael D'Amico bahwa "advertising as a persuasive message carried by a nonpersonal medium and paid for by an identified sponsor".

Menurut E. Jerome Mc Carthy dan William D. Perreault bahwa " advertising any paid form of non personal presentation of ideas, goods, or services by an identified sponsor".

Berdasarkan teori-teori di atas penulis dapat menyimpulkan bahwa advertensi adalah suatu alat untuk menginformasikan keadaan perusahaan dalam bentuk program-program yang dimiliki guna untuk menarik konsumen supaya melakukan transaksi. Adapun faktor yang mempengaruhi terhadap advertensi adalah : Pengenalan produk, pengingat kepada konsumen, pengubah persepsi, dan meningkatkan efektivitas.

\subsection{Hakikat Layanan Purna Jual}

Menurut Philip Kotler bahwa "a service any act or performance that one party can offer to another that is essentially intangible and does not result in the ownership of anything". Layanan adalah suatu kinerja bahwa satu pihak dapat menawarkan jasa yang tidak berwujud dan tidak mengharapkan imbalan. Faktor-faktor yang mempengaruhinya adalah : (a) Lebih mudah service, (b) Modern dalam pelayanan, (c) Pusat layanan.

Menurut E. Jerome Mc Carthy dan William D. Perreault bahwa "service a deed perfomed by one party for another".

Menurut Mahmud Machfoedz bahwa purna jual adalah suatu hubungan yang tidak berakhir antara konsumen dan penjual sampai dapat berlanjut karena ikatan finansial seperti pembayaran angsuran atau premi. Faktor yang mempengaruhi terhadap purna jual diantaranya :

1. Garansi yang sesuai dengan yang dijanjikan oleh pihak perusahaan atau penjual, baik karena kualitas yang rendah maupun kondisi produk yang cepat rusak.

2. Pengembalian uang dan penggantian. Garansi ditawarkan jika konsumen membeli barang, dengan perjanjian atau jaminan bahwa apabila konsumen tidak puas, maka uang akan dikembalikan atau barang kembali.

3. Ketersediaan suku cadang. Perusahaan yang efesien menjamin bahwa pada setiap produk yang dijualnya disediakan suku cadang di tempat penjualan.

4. Perawatan, pelayanan purna jual merupakan bagian penting, baik dengan membuat produk ekstra untuk distributor maupun memastikan bahwa konsumen akan mendapat manfaat maksimum dari produk.

5. Petunjuk pemakaian. Setiap petunjuk pemakaian diupayakan dapat dipahami oleh setiap konsumen dengan baik dan cara penyampaiannya seringkas mungkin dengan menggunakan kata-kata pendek, kalimat dan paragraf yang ringkas, dan menghindari istilah yang mungkin sulit dipahami.

Berdasarkan teori-teori di atas penulis dapat menyimpulkan bahwa layanan purna jual adalah hubungan yang terus menerus setelah melakukan transaksi antara konsumen dan produsen yang dimana antara satu dengan yang lainnya saling membutuhkan. Adapun faktor yang mempengaruhi terhadap layanan purnajual adalah mudah dalam pelayanan, instalasi, pemandu pemakaian dan perawatan. 


\subsection{Kerangka Berfikir}

\subsubsection{Pengaruh Advertensi Terhadap Kepuasan pelanggan}

Advertensi adalah sebuah alat sebagai perantara informasi antara perusahaan dengan konsumen, sehingga konsumen tidak susah mencari informasi yang ada di perusahaan tersebut. Kejadian-kejadian (event) adalah sesuatu yang terjadi pada saat tertentu, kesatuan nyata (fact and entity) berupa objek nyata seperti tempat, benda, dan orang yang betul-betul ada dan terjadi. Promosi adalah suatu usaha dari pemasar dalam menginformasikan dan mempengaruhi orang atau pihak lain sehingga tertarik untuk melakukan transaksi atau pertukaran produk barang atau jasa yang dipasarkannya. Jadi Informasi promo memberikan arti yang sangat penting bagi para konsumen yang akan berbelanja kebutuhannya. Oleh karena itu perusahaan sangat mengandalkan promo-promo yang di informasikan ke pelanggannya atau mencari pelanggan baru. Sehingga pelanggan merasa terlayani dan menjadi tahu dimana saja yang ada promo nya terutama yang berhubungan dengan harga. Apakah promo tersebut disampaikan melalui media cetak (Koran, surat kabar) atau media elektronik (tv, radio, website) bahkan bisa melalui sms blast dan lewat telephone (happy call).

Kepuasan pelanggan merupakan perasaan yang timbul dari pelanggan setelah melakukan evaluasi dan pemilihan terhadap perbedaan antara kinerja yang dirasakan dengan yang diharapkan. Apabila kinerja dibawah harapan, maka pelanggan akan kecewa. Bila kinerja sesuai dengan harapan, pelanggan akan puas. Namun bila kinerja melebihi dari yang diharapkan maka pelanggan akan sangat puas.

Advertensi merupakan salah satu faktor pendukung perusahaan guna mencapai target dan meningkatkan kualitas perusahaan tersebut. Terutama dalam bidang retail para pengusaha berlomba-lomba menginformasikan promo yang sedang berjalan bahkan menginformasikannya sudah jauh hari. Sudah sewajarnya setiap pembisnis melakukan persaingan adapula yang saling menjatuhkan harga sehingga banyak konsumen yang mempertimbangkan untuk belanja kemana-mananya.

Promo merupakan salah satu yang dapat mempengaruhi keunggulan bersaing, untuk unggul dalam bersaing maka setiap perusahaan berupaya menciptakan diskon besar-besaran bahkan mencapai cuci gudang yang bernilai dan memberikan manfaat kepada pelanggan secara konsisten, nilai diskon yang disampaikan ke pelanggan harus dapat dijangkau dalam pembelanjaannya. Dengan demikian dapat diduga advertensi memberikan pengaruh terhadap kepuasan pelanggan.

\subsubsection{Pengaruh Layanan Purnajual Terhadap Kepuasan Pelanggan}

Kualitas layanan merupakan penilaian konsumen setelah melakukan pengamatan langsung secara terusmenerus sebagai tanggapan atau respon terhadap jasa pelayanan atau kinerja (performance) produk atau jasa layanan yang dapat dirasakan setelah mempergunakan produk atau jasa guna memenuhi kebutuhan dan harapanharapannya.

Kepuasan pelanggan merupakan respon terhadap evaluasi spesifik yang dilakukan oleh konsumen pada keunggulan-keunggulan atas kualitas produk atau kinerja layanan yang diberikan kepada konsumen yang telah dirasakannya. Persepsi konsumen dibentuk oleh pengalaman masa lalunya pembicaraan dari mulut ke mulut serta informasi promo yang dilakukan oleh perusahaan jasa, kemudian 
dibandingkannya dengan kenyataan yang dirasakannya.

Semakin tinggi tingkat kualitas atau kinerja produk atau jasa yang ditawarkan dapat dinikmati oleh konsumen semakin tinggi tingkat kepuasan yang dirasakan oleh pelanggan. Sebaliknya semakin rendah tingkat kualitas kinerja maka semakin rendah tingkat kepercayaan yang diberikan oleh pelanggan, bahkan akan terjadi pelanggan meninggalkan perusahaan tersebut dikarenakan kurangnya pelayanan. Hampir semua perusahaan sekarang ini mengutamakan jasa pelayanan yang berkualitas dengan tujuan meraup pelanggan sebanyakbanyaknya guna untuk memperpanjang masa waktunya perusahaan.

Berdasarkan uraian di atas dapat dilihat bahwa kepuasan pelanggan sangat dipengaruhi persepsi nya atas kinerja (performance) produk dan kualitas jasa layanan serta informasi yang mengenai promosikan perusahaan dengan tujuan memberikan kepuasan kepada pelanggan dalam memenuhi harapan atau keinginannya. Dengan demikian dapat diduga bahwa terdapat pengaruh atau pengaruh positif dari persepsi kualitas layanan terhadap kepuasan pelanggan.

\subsubsection{Pengaruh Advertensi dan Layanan Purnajual secara bersama-sama Terhadap Kepuasan Pelanggan.}

Persepsi informasi promo yang difasilitasi dengan advertensi merupakan salah satu tujuan utama perusahaan yang diberikan kepada pelanggan guna memenuhi kebutuhan pelanggan. Sehingga pelanggan tidak usah repotrepot mencari informasi promo yang sedang berjalan diperusahaan tersebut. Sehingga banyak pelanggan yang mendapatkan promo dari toko retail khususnya dan bisa membandingkan perusahaan yang satu dengan yang lainnya.

Persepsi kualitas layanan merupakan penilaian pelanggan setelah melakukan pengamatan langsung secara terus-menerus sebagai tanggapan atau respon terhadap jasa pelayanan atau kinerja (performance) produk atau jasa layanan yang dapat dirasakan setelah mempergunakan produk atau jasa guna memenuhi kebutuhan dan harapanharapannya. Kepuasan pelanggan merupakan respon terhadap evaluasi spesifik yang dilakukan oleh pelanggan pada keunggulan-keunggulan atas kualitas produk atau kinerja layanan yang diberikan kepada pelanggan yang telah dirasakan.

Adanya harapan membuat pelanggan melakukan pemilihan alternatif produk atau jasa dari berbagai penyedia layanan. Pelanggan akan memutuskan pilihannya terhadap produk atau jasa layanan yang ditawarkan bila dia mengasumsikan bahwa kinerja produk atau jasa dapat mendekati atau memenuhi keinginan serta harapannya. Sebelum terjadi transaksi pelanggan lebih pintar memilih promo yang ada di suatu perusahaan tersebut, dengan begitu pelanggan sangat membutuhkan informasi promo yang sedang berjalan. Apakah informasi promo tersebut melalui media cetak seperti : koran, majalah, brosur, best buy, atau melalui media elektronik seperti : iklan tv, radio, website bahkan ada pula yang melalui sms blast atau sepanduk. Setelah pelanggan mendapatkan informasi tentang promo yang sedang berjalan, selanjutnya pelanggan akan mempertimbangakan tingkat kualitas pelayanan yang diberikan oleh perusahaan dan pada akhirnya pelanggan akan melakukan transaksi di toko tersebut.

Infomasi promo yang diberikan perusahaan dan layanan purnajual harus 
saling mendukung guna untuk memberikan kepuasan kepada pelanggan. Jangan sampai informasi promo yang diberikan perusahaan bagus tetapi pelayanannya kurang berkualitas atau sebaliknya, ini akan menyebabkan pelanggan juga meninjau kembali atas informasi promo dan pelayanan yang sedang berjalan. Dengan demikian dapat diduga bahwa ada pengaruh positif advertensi dan layanan purna jual secara bersama-sama terhadap kepuasan pelanggan.

\subsection{Hipotesis Penelitian}

Berdasarkan tinjauan teoritik, serta kerangka berfikir, maka hipotesa yang diusulkan adalah sebagai berikut :

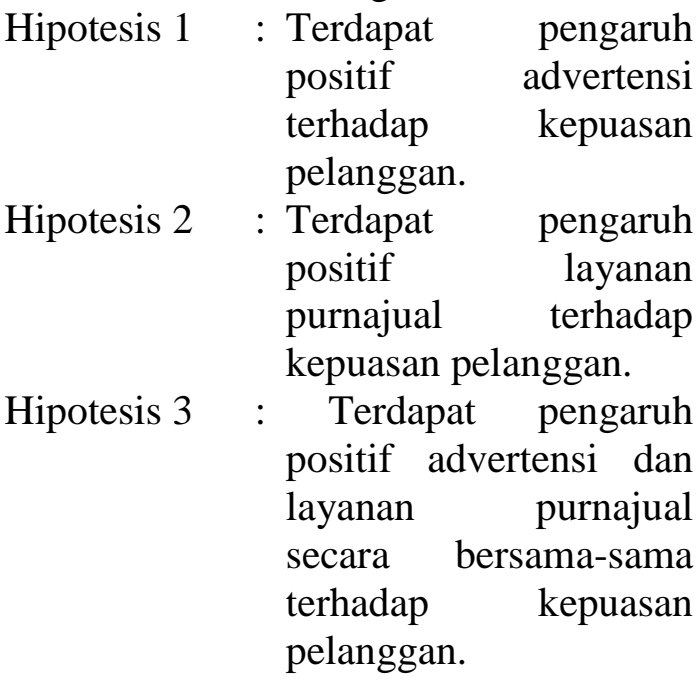

\section{Metodologi Penelitian}

Penelitian ini adalah penelitian deskriptif yang bertujuan untuk menggambarkan atau mendeskripsikan sesuatu, baik itu karakteristik atau fungsi. Penelitian ini dilakukan untuk mendapatkan gambaran mengenai variabel-variabel yang berpengaruh terhadap kepuasan pelanggan di PT Electronic City Indonesia Cabang Bogor dari variabel yang diteliti. Disain penelitian yang digunakan adalah single cross sectional yaitu pengumpulan data dari sampel tertentu yang hanya dilakukan satu kali dan pengumpulan data dilakukan dari satu responden untuk satu waktu saja, dengan menggunakan metode kuantitatif. Metode kuantitatif digunakan untuk meneliti pengaruh advertensi dan layanan purna jual terhadap kepuasan pelanggan. Metode pengambilan sampel menggunakan random sampling setiap pelanggan yang pernah belanja category LCD dan AC di PT Electronic City Cabang Bogor pada periode Oktober - Desember 2011 dan berdomisili di Kota Bogor dan sekitarnya. Sampel yang digunakan sebanyak 130 orang dengan taraf kesalahan $5 \%$. Kemudian, pengumpulan data dilakukan dengan kuesioner yang berisi pertanyaan kepuasan pelanggaan tentang variabel yang diteliti. Uji statistik yang digunakan dalam penelitian ini, yaitu uji validitas, realibilitas, uji persyaratan analisis (uji normalitas dan homogenitas), dan uji hipotesis penelitian.

\section{Hasil dan Pembahasan \\ 4.1. Deskripsi Data}

Deskripsi data hasil penelitian dimaksudkan untuk memberikan gambaran umum mengenai penyebaran data, baik berupa ukuran pengaruh advertensi, pengaruh layanan purnajual terhadap kepuasan pelanggan. Pada bagian ini dideskripsikan data hasil pengukuran daya ukur pengaruh advertensi dan layanan purnajual terhadap kepuasan pelanggan. Statistik deskriptif data tiap variabel diatas meliputi rata-rata (mean), modus, median, standar deviasi serta grafik histogram.

\subsubsection{Penilaian Pelanggan Terhadap Kepuasan Pelanggan}

Hasil penelitian menunjukkan bahwa penilaian pelanggan terhadap kepuasan pelanggan berada antara skor 91 (skor terendah) sampai dengan 133 (skor tertinggi), nilai rata-rata sebesar 
111,65, simpangan baku atau standar deviasi sebesar 10,73 sedangakan median sebesar 112 dan modus 109.
Distribusi frekuensi data hasil penelitian terhadap kepuasan pelanggan dapat dilihat pada tabel berikut ini:

Tabel 1. Distribusi Frekuensi Data Penilaian Terhadap Kepuasan Pelanggan

\begin{tabular}{|c|c|c|c|}
\hline No & Kelas Interval & Frekuensi Absolut & Frekuensi Relatif (\%) \\
\hline 1 & $91-100$ & 27 & 20,8 \\
\hline 2 & $101-110$ & 33 & 25,4 \\
\hline 3 & $111-120$ & 38 & 29,2 \\
\hline 4 & $121-130$ & 29 & 22,3 \\
\hline 5 & $131-140$ & 3 & 2,3 \\
\hline & Total & 130 & 100.0 \\
\hline
\end{tabular}

Dari data tabel distribusi di atas, jika dibandingkan dengan harga rata-rata menunjukkan bahwa nilai kepuasan pelanggan yang berada dibawah rata-rata sebanyak 60 orang responden $(46,2 \%)$, yang berada pada rata-rata sebanyak 38 responden $(29,2 \%)$ dan yang berada di atas rata-rata sebanyak 32 responden $(24,6 \%)$.

Dari variabel kepuasan pelanggan sebanyak 33 butir soal, skor teoritik terendah adalah 33 dan skor teoritik tertinggi 165 dengan median 99. Skor empirik (hasil penelitian) adalah skor terendah 91 dan skor tertinggi 133. Dengan demikian maka berdasarkan pengukuran terhadap hasil penelitian ini, kepuasan pelanggan termasuk kategori relatif tinggi.

\subsubsection{Penilaian Pelanggan Terhadap Advertensi}

Hasil penelitian menunjukkan bahwa penilaian pelanggan terhadap advertensi berada antara skor 83 (skor terendah) sampai dengan 137 (skor tertinggi), nilai rata-rata sebesar 113,24 simpangan baku atau standar deviasi sebesar 14,30 sedangakan median sebesar 115 dan modus sebesar 123.

Distribusi frekuensi data hasil penelitian pelanggan terhadap advertensi dapat dilihat pada tabel 4 berikut ini:

Tabel 2. Distribusi Frekuensi Data Penilaian Pelanggan Terhadap Advertensi

\begin{tabular}{|c|c|c|c|}
\hline No & Kelas Interval & $\begin{array}{c}\text { Frekuensi } \\
\text { Absolut }\end{array}$ & Frekuensi Relatif (\%) \\
\hline 1 & $83-92$ & 10 & 7.7 \\
\hline 2 & $93-102$ & 25 & 19.2 \\
\hline 3 & $103-112$ & 24 & 18.5 \\
\hline 4 & $113-122$ & 25 & 19.2 \\
\hline 5 & $123-132$ & 40 & 30.8 \\
\hline 6 & $133-143$ & 6 & 4.6 \\
\hline & & 130 & 100.0 \\
\hline
\end{tabular}


Dari data tabel distribusi di atas, jika dibandingkan dengan harga rata-rata menunjukkan bahwa nilai kepuasan pelanggan yang berada dibawah rata-rata sebanyak 84 orang responden $(64,6 \%)$, yang berada pada rata-rata sebanyak 40 responden $(30,8 \%)$ dan yang berada di atas rata-rata sebanyak 6 responden $(4,6 \%)$. Dari variabel advertensi sebanyak 34 butir soal, skor teoritik terendah adalah 34 dan skor teoritik tertinggi 170 dengan median 102. Skor empirik (hasil penelitian) adalah skor terendah 83 dan skor tertinggi 137. Dengan demikian maka berdasarkan pengukuran terhadap hasil penelitian ini, kepuasan pelanggan termasuk kategori relatif tinggi.

\subsubsection{Penilaian Pelanggan Terhadap Layanan Purnajual}

Hasil penelitian menunjukkan bahwa penilaian pelanggan terhadap layanan purnajual berada antara skor 86 (skor terendah) sampai dengan 145 (skor tertinggi), nilai rata-rata sebesar 121,17 simpangan baku atau standar deviasi sebesar 13,97 sedangakan median sebesar 123 dan modus sebesar 119. Distribusi frekuensi data hasil penelitian pelanggan terhadap layanan purnajual dapat dilihat pada tabel 5 berikut ini:

Tabel 3. Distribusi Frekuensi Data Penilaian Pelanggan Terhadap Layanan Purnajual

\begin{tabular}{|c|c|c|c|}
\hline No & Kelas Interval & $\begin{array}{c}\text { Frekuensi } \\
\text { Absolut }\end{array}$ & Frekuensi Relatif (\%) \\
\hline 1 & $86-95$ & 6 & 4,6 \\
\hline 2 & $96-105$ & 14 & 10,8 \\
\hline 3 & $106-115$ & 21 & 16,2 \\
\hline 4 & $116-125$ & 31 & 23,8 \\
\hline 5 & $126-135$ & 36 & 27,7 \\
\hline 6 & $136-145$ & 22 & 16,9 \\
\hline & & 130 & 100,0 \\
\hline
\end{tabular}

Dari data tabel distribusi di atas, jika dibandingkan dengan harga rata-rata menunjukkan bahwa nilai kepuasan pelanggan yang berada dibawah rata-rata sebanyak 72 orang responden (85\%), yang berada pada rata-rata sebanyak 36 responden $(27,7 \%)$ dan yang berada di atas rata-rata sebanyak 22 responden $(16,9 \%)$. Dari variabel layanan purnajual sebanyak 36 butir soal, skor teoritik terendah adalah 36 dan skor teoritik tertinggi 180 dengan median 108. Skor empirik (hasil penelitian) adalah skor terendah 86 dan skor tertinggi 145 . Dengan demikian maka berdasarkan pengukuran terhadap hasil penelitian ini, kepuasan pelanggan termasuk kategori relatif tinggi.

\subsection{Pengujian Persyaratan Analisis}

Analisis yang digunakan dalam pengujian hipotesis adalah analisis regresi. Analisis ini di perkenankan apabila ketiga variabel yang dianalisis berasal dari populasi yang berdistribusi normal. Oleh karena itu sebelum dilakukan pengujian hipotesis dilakukan pengujian normalitas dari data kepuasan pelanggan $(\mathrm{Y})$, penilaian pelanggan terhadap advertensi $\left(\mathrm{X}_{1}\right)$, dan layanan purnajual $\left(\mathrm{X}_{2}\right)$.

Normalitas data dikatakan valid untuk pengujian hipotesis, apabila data 
tersebut mempunyai distribusi normal dan bersifat homogen. Pengujian normalitas data dilakukan dengan rumus Chi Kuadrat dan uji homogenitas dengan rumus Barlett.

\section{Uji Normalitas}

a. Uji Normalitas Galat Baku Taksiran Persamaan Regresi Variabel Advertensi $\left(\mathrm{X}_{1}\right)$ terhadap Kepuasan Pelanggan (Y).

Uji dari normalitas adalah uji yang dipergunakan untuk melihat apakah data yang digunakan berdistribusi normal atau tidak. Pengujian normalitas menggunakan uji statistik Liliefors. Pengujian normalitas galat baku taksiran $\mathrm{Y}$ dan $\mathrm{X}$ dimaksudkan untuk menguji apakah galat baku taksiran $\mathrm{H}_{0}$ : ( $\mathrm{Y}$ - Yे) berdistribusi normal, $\mathrm{H}_{1}$ : $(\mathrm{Y}-\dot{\mathrm{Y}})$ tidak berdistribusi normal. Kriteria pengujian yang dilakukan adalah $\mathrm{H}_{0}$ diterima apabil $\mathrm{L}_{0}<\mathrm{L}_{\mathrm{t}}$ artinya $\mathrm{H}_{0}$ ditolak.

Berdasarkan perhitungan uji normalitas galat baku taksiran (Y - Ỳ) persamaan regresi antara variabel advertensi $\left(\mathrm{X}_{1}\right)$ dengan variabel kepuasan pelanggan $(\mathrm{Y})$, diperoleh nilai terbesar luas daerah $\left(\mathrm{L}_{\mathrm{o}} \max \right)=0,0322$, sementara $\mathrm{L}_{\text {tabel }}$ untuk $\mathrm{n}=130$ dan taraf signifikansi $=0,05$ sebesar 0,0777. Persyaratan galat baku berdistribusi normal adalah jika $\mathrm{L}_{0}<\mathrm{L}_{\mathrm{t}}$.
Dengan demikian, galat baku taksiran (Y - Ỳ) persamaan regresi antara variabel advertensi $\left(\mathrm{X}_{1}\right)$ dengan variabel kepuasan pelanggan $(\mathrm{Y})$ berasal dari populasi yang berdistribusi normal, karena $\mathrm{L}_{0}$ sebesar 0,0322 $<\mathrm{L}_{\mathrm{t}}$ sebesar 0,0777 pada taraf signifikansi $\alpha=0,05$ dan $n=130$.

b. Uji Normalitas Galat Baku Taksiran Persamaan Regresi antara Variabel Layanan Purnajual $\left(\mathrm{X}_{2}\right) \quad$ terhadap Kepuasan Pelanggan (Y)

Berdasarkan perhitungan uji normalitas galat baku taksiran (Y - Ỳ) persamaan regresi antara variabel layanan purnajual $\left(\mathrm{X}_{2}\right)$ dengan variabel kepuasan pelanggan (Y), diperoleh nilai terbesar luas daerah $\left(\mathrm{L}_{\mathrm{o}} \max \right)=$ 0,0487, sementara $L_{\text {tabel }}$ untuk $n$ $=130$ dan taraf signifikansi = 0,05 sebesar 0,0777 . Persyaratan galat baku berdistribusi normal adalah jika $\mathrm{L}_{0}<\mathrm{L}_{\mathrm{t}}$.

Dengan demikian, galat baku taksiran (Y - Ỳ) persamaan regresi antara variabel layanan purnajual $\left(\mathrm{X}_{2}\right)$ dengan variabel kepuasan pelanggan ( $\mathrm{Y}$ ) berasal dari populasi yang berdistribusi normal, karena $\mathrm{L}_{0}$ sebesar 0,0487 $<\mathrm{L}_{\mathrm{t}}$ sebesar 0,0777 pada taraf signifikansi $\alpha=0,05$ dan $\mathrm{n}=130$.

Tabel 4. Rangkuman Uji Normalitas Data dengan menggunakan Rumus Liliefors

\begin{tabular}{|c|c|c|c|c|}
\hline No & Galat & Lo Maks & $\mathrm{L}_{\text {tabel }} \alpha=0,05$ & Kesimpulan \\
\hline 1 & $\mathrm{Y}-\dot{\mathrm{Y}}$ & 0,0322 & 0,0777 & Normal \\
\hline 2 & $\mathrm{Y}-\dot{\mathrm{Y}}$ & 0,0487 & 0,0777 & Normal \\
\hline \multicolumn{5}{|c|}{ Syarat normal Lh $<\mathrm{Lt}$} \\
\hline
\end{tabular}

2. Uji Homogenitas a. Uji Homogenitas Kepuasan Pelanggan (Y) atas Advertensi $\left(\mathrm{X}_{1}\right)$ 
Homogenitas varians data variabel kepuasan pelanggan $(\mathrm{Y})$ atas advertensi $\left(\mathrm{X}_{1}\right)$ diuji dengan menggunakan uji barlett. Berdasarkan hasil perhitungan, diperoleh $X_{\text {hitung }}=38,121$, sedangkan $\mathrm{X}_{\text {tabel }}^{2}$ untuk $\mathrm{dk}=30$ dan taraf signifikansi $=0,05$ sebesar 43,773. Persyaratan varians homogen adalah jika $\mathrm{X}_{\text {hitung }}^{2}<\mathrm{X}_{\text {tabel. }}^{2}$ Dengan demikian varians data kepuasan pelanggan ( $\mathrm{Y}$ ) atas advertensi $\left(\mathrm{X}_{1}\right)$ berasal dari populasi yang homogen, karena $\mathrm{X}^{2}$ hitung $<$ sebesar $=38,121<\mathrm{X}_{\text {tabel }}^{2}$ sebesar $=43,773$.

b. Uji Homogenitas Kepuasan Pelanggan (Y) atas Layanan Purnajual $\left(\mathrm{X}_{2}\right)$
Homogenitas varians data variabel kepuasan pelanggan $(\mathrm{Y})$ atas layanan purnajual $\left(\mathrm{X}_{2}\right)$ diuji dengan menggunakan uji barlett. Berdasarkan hasil perhitungan, diperoleh $\mathrm{X}^{2}$ hitung $=36,203$ sedangkan $\mathrm{X}_{\text {tabel }}^{2}$ untuk $\mathrm{dk}=30$ dan taraf signifikansi $=0,05$ sebesar 43,773. Persyaratan varians homogen adalah jika $\mathrm{X}_{\text {hitung }}^{2}<\mathrm{X}_{\text {tabel. }}^{2}$ Dengan demikian varians data kepuasan pelanggan (Y) atas layanan purnajual $\left(\mathrm{X}_{2}\right)$ berasal dari populasi yang homogen, karena $\mathrm{X}^{2}$ hitung $<$ sebesar $=36,203<$ $X^{2}$ tabel sebesar $=43,773$.

Tabel 5. Uji Homogenitas Varians Data Variabel $(\mathrm{Y})$ atas Variabel $\left(\mathrm{X}_{1}\right)$ dan $\left(\mathrm{X}_{2}\right)$

\begin{tabular}{|c|c|c|c|c|c|c|}
\hline No & Varian yang diuji & $\begin{array}{c}\text { Jumlah } \\
\text { sampel }\end{array}$ & $\mathrm{dk}$ & $\mathrm{X}_{\text {hitung }}^{2}$ & $\mathrm{X}_{\text {tabel }}(\alpha=0,05)$ & Kesimpulan \\
\hline 1 & Variabel Y atas $\mathrm{X}_{1}$ & 130 & 30 & 38,121 & 43,773 & Homogen \\
\hline 2 & Variabel Y atas $\mathrm{X}_{2}$ & 130 & 30 & 36,203 & 43,773 & Homogen \\
\hline \multicolumn{7}{|c|}{ Persyaratan homogen $\mathrm{X}_{\text {hitung }}^{2}<\mathrm{X}_{\text {tabel }}^{2}$} \\
\hline
\end{tabular}

\section{Uji Linearitas}

Untuk memenuhi persyaratan regresi maka perlu dilakukan uji linearitas pada dependent variabel dengan independent variabel dengan kriteria uji apabila nilai $\mathrm{F}_{\text {hitung }}<\mathrm{F}_{\text {tabel }}$ dengan tingkat $\alpha=0,05$ yang telah ditentukan maka distribusi dependent variabel dengan independent variabel berpola linear.

a. Uji Linearitas Advertensi $\left(\mathbf{X}_{1}\right)$ terhadap Kepuasan Pelanggan (Y)
Uji linearitas sebagai salah satu persyaratan untuk menggunakan regresi linear sederhana menunjukkan bahwa variabel advertensi terhadap kepuasan pelanggan memperlihatkan nilai $\mathrm{F}_{\text {hitung }}=$ $0,98<\mathrm{F}_{\text {tabel }}=1,54$ mencapai taraf signifikan pada tingkat $\alpha=0,05$ yang digunakan, berdasarkan hasil perhitungan uji linearitas seperti terlihat pada tabel 6 sehingga distribusi data variabel advertensi dan variabel kepuasan pelanggan.

Tabel 6. Analisis Varians (ANAVA)

\begin{tabular}{|c|c|c|c|c|c|c|c|}
\hline \multirow{2}{*}{$\begin{array}{c}\text { SUMBER } \\
\text { VARIANS }\end{array}$} & $\mathrm{dk}$ & $\mathrm{JK}$ & $\mathrm{KT}$ & \multirow{2}{*}{$\mathrm{F}_{\text {hitung }}$} & \multicolumn{2}{|c|}{$\mathrm{F}_{\text {tabel }}$} & \multirow{2}{*}{ Kesimpulan } \\
\cline { 5 - 7 } & & & & $\dot{\alpha}=0,05$ & $\dot{\alpha}=0,01$ & \\
\hline Total & 130 & $1,635,511$ & $1,635,511$ & & & & \\
\hline
\end{tabular}




\begin{tabular}{|c|c|c|c|c|c|c|c|}
\hline Koefisien (a) & 1 & $1,630,245$ & $1,630,245$ & & & & \\
\hline Regresi (b/a) & 1 & 463 & 463 & \multirow{2}{*}{$12.33^{* *}$} & \multirow{2}{*}{3.92} & \multirow{2}{*}{6.84} & \multirow{2}{*}{$\begin{array}{c}\text { Sangat } \\
\text { signifikan }\end{array}$} \\
\hline Sisa & 128 & 4,803 & 37.53 & & & & \\
\hline Tuna cocok & 45 & 1,664 & 36.98 & \multirow{2}{*}{$0.98^{\mathrm{ns}}$} & \multirow{2}{*}{1.54} & & \multirow{2}{*}{ Linear } \\
\hline Galat & 83 & 3,139 & 37.82 & & & & \\
\hline
\end{tabular}

Keterangan :

** $\quad=$ Sangat signifikan

ns $\quad=$ Non signifikan

$\mathrm{dk} \quad=$ Derajat kebebasan

$\mathrm{JK} \quad=$ Jumlah Kuadrat

RJK = Rata-rata Jumlah Kuadrat

Kesimpulan yang dapat ditarik adalah persamaan regresi tersebut linear.

\section{b. Uji Linearitas Layanan Purnajual $\left(\mathrm{X}_{2}\right)$ terhadap Kepuasan Pelanggan (Y)}

Uji linearitas sebagai salah satu persyaratan untuk menggunakan regresi linear sederhana menunjukkan bahwa variabel layanan purnajual terhadap kepuasan pelanggan memperlihatkan nilai $\mathrm{F}_{\text {hitung }}=0,81<\mathrm{F}_{\text {tabel }}=1,51$ mencapai taraf signifikan pada tingkat $\alpha$ $=0,05$ yang digunakan, berdasarkan hasil perhitungan uji linearitas seperti terlihat pada tabel 7 sehingga distribusi data variabel layanan purnajual dan kepuasan pelanggan berpola linear.

Tabel 7. Analisis Varians (ANAVA)

\begin{tabular}{|c|c|c|c|c|c|c|c|}
\hline \multirow{2}{*}{$\begin{array}{c}\text { SUMBER } \\
\text { VARIANS }\end{array}$} & \multirow{2}{*}{$\mathrm{dk}$} & \multirow{2}{*}{ JK } & \multirow{2}{*}{ KT } & \multirow{2}{*}{$F_{\text {hitung }}$} & \multicolumn{2}{|c|}{$\mathrm{F}_{\text {tabel }}$} & \multirow{2}{*}{ Kesimpulan } \\
\hline & & & & & $\dot{\alpha}=0,05$ & $\alpha=0,01$ & \\
\hline Total & 130 & $1,635,511$ & $1,635,511$ & & & & \\
\hline Koefisien (a) & 1 & $1,629,488$ & $1,629,488$ & & & & \\
\hline Regresi (b/a) & 1 & 771 & 771 & \multirow{2}{*}{$18.80^{* * *}$} & \multirow{2}{*}{3.92} & \multirow{2}{*}{6.84} & \multirow{2}{*}{$\begin{array}{c}\text { Sangat } \\
\text { signifikan }\end{array}$} \\
\hline Sisa & 128 & 5,252 & 41.03 & & & & \\
\hline Tuna cocok & 47 & 1,678 & 35.69 & \multirow{2}{*}{$0.81^{\mathrm{ns}}$} & \multirow{2}{*}{1.51} & & \multirow{2}{*}{ Linear } \\
\hline Galat & 81 & 3,574 & 44.12 & & & & \\
\hline
\end{tabular}

Keterangan :

$$
\begin{array}{ll}
* * & =\text { Sangat signifikan } \\
\mathrm{ns} & =\text { Non signifikan } \\
\mathrm{dk} & =\text { Derajat kebebasan } \\
\mathrm{JK} & =\text { Jumlah Kuadrat } \\
\text { RJK } & =\text { Rata-rata Jumlah Kuadrat }
\end{array}
$$

Kesimpulan yang dapat ditarik adalah persamaan regresi tersebut linear.

\subsection{Pengujian Hipotesis}

Dalam penelitian ini terdapat tiga hipotesis yang akan diuji dengan statistik 
infrensia melalui teknik analisis regresi. Hipotesis pertama dan kedua diuji dengan teknik analisis regresi, sedangkan hipotesis ketiga diuji dengan menggunakan regresi. pengujian tersebut secara rinci diuraikan sebagai berikut :

\section{Pengaruh Advertensi Terhadap Kepuasan Pelanggan}

Hasil

penelitian

menunjukkan "terdapat pengaruh positif dan signifikan advertensi terhadap kepuasan pelanggan'. Dengan kata lain bahwa semakin tinggi advertensi yang disampaikan, semakin tinggi kepuasan pelanggan, dan sebaliknya semakin rendah advertensi maka semakin rendah kepuasan pelanggan.

$$
\text { Variabel advertensi }
$$

menghasilkan arah regresi positif dengan b sebesar 0,347 dan konstanta a sebesar 72,406. Dengan demikian bentuk hubungan antara kedua variabel tersebut dapat digambarkan oleh persamaan regresi $\hat{Y}=72,406+0,347 X_{1}$. Sebelum digunakan untuk keperluan prediksi, persamaan regresi ini harus memenuhi syarat kelinearan dan keberartian.

Berdasarkan hasil pengujian linearitas seperti pada tabel 6 dimana $\mathrm{F}_{\text {hitung }}=12,33>\mathrm{F}_{\text {tabel }}=3,92$ disimpulkan bahwa regresi signifikan dan linear.

Persamaan regresi $\hat{\mathrm{Y}}=72,406+$ $0,347 \mathrm{X}_{1}$. Regresi ini mengandung arti bahwa apabila advertensi dinaikkan sebesar 1 satuan maka kepuasan pelanggan diprediksi akan bertambah 0,347 satuan dengan konstanta 72,406. Variabel advertensi dapat digunakan untuk memprediksi secara signifikan kepuasan pelanggan.

\section{Pengaruh Layanan Purnajual Terhadap Kepuasan Pelanggan.}

Hasil

penelitian

menunjukkan "terdapat pengaruh positif dan signifikan layanan purnajual terhadap kepuasan pelanggan', Dengan kata lain bahwa semakin tinggi layanan purnajual yang diberikan, semakin tinggi kepuasan pelanggan, dan sebaliknya semakin rendah layanan purnajual maka semakin rendah kepuasan pelanggan.

Variabel layanan purnajual menghasilkan arah regresi positif dengan b sebesar 0,365 dan konstanta a sebesar 67,375. Dengan demikian bentuk hubungan antara kedua variabel tersebut dapat digambarkan oleh persamaan regresi $\hat{Y}=67,375+0,365 X_{2}$. Sebelum digunakan untuk keperluan prediksi, persamaan regresi ini harus memenuhi syarat kelinearan dan keberartian.

Berdasarkan hasil pengujian linearitas seperti pada tabel 7 dimana $\mathrm{F}_{\text {hitung }}=18,80>\mathrm{F}_{\text {tabel }}=3,92$ disimpulkan bahwa regresi signifikan dan linear.

Persamaan regresi $\hat{Y}=67,375+$ $0,365 \mathrm{X}_{2}$. Regresi ini mengandung arti bahwa apabila layanan purnajual dinaikkan sebesar 1 satuan maka kepuasan pelanggan diprediksi akan bertambah 0,365 satuan dengan konstanta 67,375. Variabel layanan purnajual dapat digunakan untuk memprediksi secara signifikan kepuasan pelanggan.

\section{Pengaruh Advertensi dan Layanan Purnajual Secara Bersama-sama Terhadap Kepuasan Pelanggan}

Hasil penelitian menunjukkan "terdapat pengaruh positif dan signifikan advertensi dan layanan purnajual secara bersama-sama terhadap kepuasan pelanggan". Dengan kata lain semakin tinggi advertensi yang disampaikan dan layanan purnajual yang diberikan, semakin tinggi kepuasan pelanggan, dan sebaliknya semakin rendah advertensi dan layanan purnajual maka kepuasan pelanggan semakin rendah.

Variabel

advertensi menghasilkan arah regresi positif dengan $b_{1}$ sebesar 0,347 dan konstanta a 72,406 untuk $b_{2}$ sebesar 0,365 dan konstanta a sebesar 67,375. Dengan demikian bentuk 
hubungan antara ketiga variabel tersebut dapat digambarkan oleh persamaan regresi $\hat{\mathrm{Y}}=42,871+0,283 \mathrm{X}_{1}+0,303$ $\mathrm{X}_{2}$. Sebelum digunakan untuk keperluan prediksi, persamaan regresi ini harus memenuhi syarat keberartian.
Untuk mengetahui derajat keberartian dan linearan persamaan regresi, dilakukan uji $\mathrm{F}$ dan hasilnya dapat dilihat pada tabel 15 di bawah ini :

\section{DAFTAR ANALISIS VARIANS (ANAVA) REGRESI LINEAR GANDA}

\begin{tabular}{|c|c|c|c|c|c|c|c|}
\hline \multirow{2}{*}{ SUMBER } & \multirow{2}{*}{ VARIANS } & \multirow{2}{*}{$\mathrm{JK}$} & \multirow{2}{*}{$\mathrm{RJK}$} & \multirow{2}{*}{$\mathrm{F}_{\text {hitung }}$} & \multicolumn{2}{|c|}{$\mathrm{F}_{\text {tabel }}$} & \multirow{2}{*}{ Kesimpulan } \\
\cline { 1 - 3 } & & & & & $\alpha=0,05$ & $\dot{\alpha}=0,01$ & \\
\hline Total & 129 & & & & & & \\
\hline Regresi & 2 & 5.373 & 2.687 & \multirow{2}{*}{$27,33^{* *}$} & $3,07^{\text {ns }}$ & 4,78 & Sangat signifikan \\
\hline Sisa & 127 & 12.482 & 98,28 & & & & \\
\hline
\end{tabular}

Keterangan :

$\begin{array}{ll}* * & =\text { Sangat signifikan } \\ \mathrm{ns} & =\text { Non signifikan } \\ \mathrm{dk} & =\text { Derajat kebebasan } \\ \mathrm{JK} & =\text { Jumlah Kuadrat } \\ \text { RJK } & =\text { Rata-rata Jumlah Kuadrat }\end{array}$

Persamaan regresi $\hat{Y}=42,871+0,283$ $\mathrm{X}_{1}+0,303 \mathrm{X}_{2}$ ini mengandung arti bahwa apabila advertensi dan layanan purnajual dinaikkan sebesar 1 satuan maka kepuasan pelanggan diprediksi akan bertambah 0,586 satuan dengan konstanta 42,871. Variabel advertensi dan layanan purnajual dapat digunakan untuk memprediksi secara signifikan kepuasan pelanggan.

\subsection{Pembahasan Hasil Penelitian}

Dari keseluruhan analisis kuantitatif yang dilakukan pada ketiga variabel diatas, dijelaskan bahwa kepuasan pelanggan adalah perasaan yang timbul pada konsumen dalam bentuk senang atau kecewa yang berawal dari sebuah transaksi. Advertensi adalah suatu alat untuk menginformasikan keadaan perusahaan dalam bentuk program-program yang dimiliki guna untuk menarik konsumen supaya melakukan transaksi. Layanan purna jual adalah hubungan yang terus menerus setelah melakukan transaksi antara konsumen dan produsen yang dimana antara satu dengan yang lainnya saling membutuhkan. Diketahui pula bahwa terdapat pengaruh positif advertensi terhadap kepuasan pelanggan, pengaruh positif layanan purnajual terhadap kepuasan pelanggan dan pengaruh positif advertensi dan layanan purnajual secara bersama-sama terhadap kepuasan pelanggan.

\section{Pengaruh Advertensi terhadap kepuasan pelanggan}

Hasil penelitian menunjukkan "terdapat pengaruh positif dan signifikan advertensi terhadap kepuasan pelanggan". Dengan kata lain bahwa semakin tinggi advertensi yang disampaikan, semakin tinggi kepuasan pelanggan, dan sebaliknya semakin rendah advertensi yang diberikan maka semakin rendah pula kepuasan pelanggannya. 
Persamaan regresi $\hat{Y}=72,406+$ $0,347 \mathrm{X}_{1}$. Regresi ini mengandung arti bahwa apabila advertensi dinaikkan sebesar 1 satuan maka kepuasan pelanggan diprediksi akan bertambah 0,347 satuan dengan konstanta 72,406. Variabel advertensi dapat digunakan untuk memprediksi secara signifikan kepuasan pelanggan.

Iwan Gunawan, hasil penelitiannya diketahui terdapat pengaruh positif advertensi terhadap kepuasan pelanggan. Artinya semakin tinggi advertensi yang disampaikan perusahaan maka kepuasan pelanggan akan semakin meningkat. Hal ini ditunjukkan oleh persamaan regresi $\hat{Y}=$ $63,25+0,34 \mathrm{X}_{1}$. Artinya apabila advertensi dinaikkan sebesar 1 satuan maka kepuasan pelanggan diprediksi akan bertambah sebesar 0,34 satuan dengan konstanta 63,25. Variabel advertensi dapat digunakan untuk memprediksi secara signifikan kepuasan pelanggan.

\section{Pengaruh Layanan Purnajual terhadap Kepuasan Pelanggan}

Hasil

penelitian

menunjukkan "terdapat pengaruh positif dan signifikan layanan purnajual terhadap kepuasan pelanggan'. Dengan kata lain bahwa semakin tinggi layanan purnajual yang diberikan, maka semakin tinggi kepuasan pelanggan, dan sebaliknya semakin rendah layanan purnajual maka semakin rendah kepuasan pelanggan.

Persamaan regresi $\hat{\mathrm{Y}}=67,375+$ $0,365 \mathrm{X}_{2}$. Regresi ini mengandung arti bahwa apabila layanan purnajual dinaikkan sebesar 1 satuan maka kepuasan pelanggan diprediksi akan bertambah 0,365 satuan dengan konstanta 67,375. Variabel layanan purnajual dapat digunakan untuk memprediksi secara signifikan kepuasan pelanggan.
Iim Rohimah, hasil penelitiannya diketahui terdapat pengaruh yang positif fasilitas pelayanan jasa gadai terhadap kepuasan pelanggan dengan persamaan regresi $\hat{Y}=59,57+0,56 X_{2}$. Artinya, apabila fasilitas pelayanan dinaikkan sebesar 1 satuan maka kepuasan pelanggan diprediksi akan bertambah sebesar 0,56 satuan dengan konstanta 59,57. Variabel fasilitas pelayanan dapat digunakan untuk memprediksi secara signifikan kepuasan pelanggan.

\section{Pengaruh Advertensi dan Layanan Purnajual Secara Bersama-sama Terhadap Kepuasan Pelanggan}

Hasil penelitian menunjukkan "terdapat pengaruh positif dan signifikan advertensi dan layanan purnajual secara bersama-sama terhadap kepuasan pelanggan". Dengan kata lain semakin tinggi advertensi yang disampaikan dan layanan purnajual yang diberikan, maka semakin tinggi kepuasan pelanggan, dan sebaliknya semakin rendah advertensi dan layanan purnajual maka kepuasan pelanggan semakin rendah.

Persamaan regresi $\hat{Y}=42,871+$ $0,283 X_{1}+0,303 X_{2}$ ini mengandung arti bahwa apabila advertensi dan layanan purnajual dinaikkan sebesar 1 satuan maka kepuasan pelanggan diprediksi akan bertambah 0,586 satuan dengan konstanta 42,871. Variabel advertensi dan layanan purnajual dapat digunakan untuk memprediksi secara signifikan kepuasan pelanggan.

\section{Penutup}

\subsection{Kesimpulan}

Berdasarkan uraian pembahasan dan analisis pengaruh advertensi dan layanan purnajual terhadap kepuasan pelanggan, maka penulis memberikan kesimpulan sebagai berikut :
1. Terdapat
pengaruh
advertensi
terhadap
kepuasan
pelanggan.
Advertensi mempunyai pengaruh 
yang signifikan $(\alpha=0,05)$ terhadap kepuasan pelanggan. Dengan persamaan regresi $\hat{\mathrm{Y}}=72,406+$ $0,347 \mathrm{X}_{1}$. Regresi ini mengandung arti bahwa apabila advertensi dinaikkan sebesar 1 satuan maka kepuasan pelanggan diprediksi akan bertambah 0,347 satuan dengan konstanta 72,406.

2. Terdapat pengaruh layanan purnajual terhadap kepuasan pelanggan. Layanan purnajual mempunyai pengaruh yang signifikan $(\alpha=0,05)$ terhadap kepuasan pelanggan. Dengan persamaan regresi $\hat{Y}=$ $67,375+0,365 X_{2}$. Regresi ini mengandung arti bahwa apabila layanan purnajual dinaikkan sebesar 1 satuan maka kepuasan pelanggan diprediksi akan bertambah 0,365 satuan dengan konstanta 67,375.

3. Terdapat pengaruh advertensi dan layanan purnajual secara bersamasama terhadap kepuasan pelanggan. Advertensi dan layanan purnajual secara bersama-sama memiliki pengaruh yang signifikan $(\alpha=0,05)$ terhadap kepuasan pelanggan. Dengan persamaan regresi $\hat{Y}=$ $42,871+0,283 X_{1}+0,303 X_{2}$. Regresi ini mengandung arti bahwa apabila advertensi dan layanan purnajual dinaikkan sebesar 1 satuan maka kepuasan pelanggan diprediksi akan bertambah 0,586 satuan dengan konstanta 42,871.

\subsection{Implikasi}

Hasil penelitian ini sebagaimana kesimpulan-kesimpulan diatas memberikan implikasi bahwa kepuasan pelanggan harus terus menerus ditingkatkan melalui upaya-upaya peningkatan advertensi yang disampaikan serta layanan purna jual yang diberikan. Adapun yang harus ditingkatkan diantaranya :
1. Upaya peningkatan advertensi terhadap kepuasan pelanggan.

Peningkatan advertensi yang disampaikan perusahaan dapat meningkatkan kepuasan pelanggan. Upaya lain untuk meningkatkan advertensi yaitu menyampaikan pesan yang tepat sasaran kepada pelanggan sehingga pelanggan merasa puas. Sebaliknya jika terjadi penurunan advertensi yang disampaikan maka akan terjadi penurunan kepuasan pelanggan dan akan menyebabkan suatu kekecewaan pelanggan.

2. Upaya peningkatan layanan purnajual terhadap kepuasan pelanggan

Peningkatan layanan purnajual yang diberikan perusahaan dapat meningkatkan kepuasan pelanggan. Upaya lain untuk meningkatkan layanan purnajual yaitu memberikan pelayanan yang secara terus menerus kepada pelanggan dengan mengupayakan jauh dari komplainan. Sebaliknya jika terjadi penurunan layanan purnajual maka akan terjadi penurunan kepuasan pelanggan dan akan menyebabkan suatu kekecewaan pelanggan.

3. Upaya peningkatan advertensi dan layanan purnajual secara bersamasama terhadap kepuasan pelanggan.

Peningkatan advertensi dan layanan purnajual secara bersamasama dapat meningkatkan kepuasan pelanggan. Dua hal ini harus dijaga secara terus-menerus oleh perusahaan, dan harus menjadi sebuah standarisasi perusahaan supaya pelanggan mengenal lebih jauh lagi terhadap perusahaan. Sebaliknya jika ada penurunan advertensi yang disampaikan dan penurunan layanan purnajual secara bersama-sama, maka akan terjadi pula penurunan kepuasan pelanggan 
yang nantinya akan meninmbulkan kekecewaan pelanggan.

\subsection{Saran}

Berdasarkan uraian dari kesimpulan dan implikasi diatas, maka dapat diajukan beberapa saran terutama yang berkaitan dengan peningkatan pelanggan melalui advertensi dan layanan purnajual, sebagai berikut :

1. Memberikan saran untuk Meningkatkan Kepuasan Pelanggan

a. Kebutuhan pribadi

Upaya peningkatan kepuasan pelanggan ditujukan dalam kebutuhan pribadi pelanggan. Perusahaan harus menjadikan semua barang yang dibeli oleh pelanggan merupakan suatu kebutuhan pribadi. Dan memberikan kesan bahwa barang yang dibeli nya itu sangat dibutuhkan pelanggan.

b. Pengalaman masa lampau

Peningkatan kepuasan pelanggan dapat terjadi pada pengalaman masa lampau nya. Jika terjadi kesalahan maka akan menimbulkan kecewa bagi pelanggan dan akan mempengaruhi ke yang lainnya. Untuk itu perusahaan harus bisa menjaga nama baik dan perlunya ditingkatkan pelayanan dan menghindari dari kesalahan.

c. Kesesuaian spesifikasi

Barang yang dijual harus sesuai dengan spesifikasinya. Untuk itu perusahaan harus teliti memeriksa barang yang akan dijualnya dan harus peduli terhadap barang-barang yang tidak sesuai spesifikasi. Jika hal itu terjadi maka akan menimbulkan komplainan pelanggan.

d. Kualitas produk
Kualitas produk sangat penting diperhatikan untuk memenuhi kebutuhan dan kepuasan pelanggan. Perusahaan harus lebih teliti terhadap barang yanga dijualnya, harus dijaga keasliannya, harus konsisten dalam memeriksa barang yang dijualnya. Jika itu tidak dijalankan maka yang terjadi hanyalah sebuah komplain pelanggan.

2. Memberikan saran untuk meningkatkan Advertensi

a. Pengenalan produk

Pengenalan produk kepada pelanggan merupakan langkah awal untuk peningkatan advertensi. Salah satu keberhasilan dalam advertensi yaitu pengenalan produk harus pas sasarannya. Jika ada produk baru perusahaan harus cepatcepat dikenalkan ke pelanggan untuk dijualnya. Pengenalan produk baru juga merupakan salah satu pendukung untuk meningkatkan advertensi.

b. Pengingat kepada konsumen

Advertensi yang disampaikan ke konsumen harus menjadi pengingat, supaya kemanapun dan dimanapun berada selalu ingat ke perusahaan atas kebutuhannya itu. Jika tidak demikian maka akan ditinggal oleh orang banyak, sehubungan banyak perusahaan yang sama.

c. Pengubah persepsi

Advertensi juga harus menjadikan pengubah persepsi, yang dimana setiap pelanggan yang datang ke perusahaan dengan tujuan membeli sekalipun yang dicarinya tidak ada tetapi ada pengganti barang yang lainnya dengan tujuan mengubah persepsi pelanggan yang datang. 
Jika itu tidak dijalankan maka pelanggan yang datang ke perusahaan hanya bertujuan untuk melihat-lihat saja tanpa adanya suatu transaksi.

d. Meningkatkan efektivitas

Dengan adanya peningkatan advertensi itu harus menambah efektivitas perusahaan dan menjadikan sebuah kegiatan yang rutinitas. Harus menjadikan panambahan pelanggan yang secara terus menerus ada dengan tujuan berbelanja. Jika hal itu tidak ada pengaruhnya maka yang terjadi hanya sedikit pelanggan yang datang.

3. Memberikan saran untuk meningkatkan layanan purnajual

a. Mudah dalam pelayanan

Memudahkan dalam pelayanan setelah terjadi penjualan itu merupakan salah satu cara untuk meningkatkan dalam layanan purnajual. Sehingga pelanggan tidak susah untuk memperbaiki barang yang dibelinya jika terjadi suatu kerusakan. Tidak hanya untuk melayani jasa kerusakan saja tetapi harus memberikan kemudahan dalam pengiriman barang kerumah pelanggan sehingga pelanggan tidak susah dalam penerimaan barang dirumahnya. Jika itu tidak diberjalankan maka pelanggan akan menimbulkan sebuah komplainan dan suatu saat akan meninggalkan perusahaan.

b. Instalasi

Instalasi barang yang dibeli pelanggan merupakan layanan purnajual perusahaan yang harus dijalankan. Memberikan kemudahan dalam instalasi dan tepat waktu itu akan memberikan nilai plus bagi perusahaan. Jangan sampai menunda bahkan telat dalam penginstalannya. Jika hal itu terjadi maka pelanggan akan komplain dan kecewa bahkan tidak akan datang lagi ke perusahaan.

c. Pemandu pemakaian

Pelanggan menginginkan barang yang dibelinya itu mudah dalam pemakaiannya dan praktis, untuk itu perusahaan harus memberikan buku panduan yang jelas dalam penggunaan barangnya dan mudah dimengerti, jika perlu sebelum barang dijual ke pelanggan terlebih dahulu harus diberitahukan kegunaannya. Jika hal itu tidak dilakukan maka pelanggan tidak akan membelinya dan memberikan kebingungan ke pelanggan sendiri.

d. Perawatan

Upaya dalam peningkatan layanan purnajual terletak pada perawatan dan service secara rutinitas. Untuk itu perusahaan seharusnya meningkatkan yang lebih guna memberikan pelayanan yang secara terus menerus dan menjadikan pelanggan nyaman sehingga pelanggan pun juga akan datang kembali ke perusahaan untuk berbelanja guna memenuhi kebutuhannya. Jika itu tidak dilakukan perusahaan maka yang terjadi pelanggan akan meninggalkan perusahaan dan pindah ke yang lain.

\section{DAFTAR PUSTAKA}

Arif Rahman. Strategi Dahsyat Marketing Mix. Jakarta : Trans Media Pustaka, 2010.

Boediono dan Wayan Koster. Statistik dan Probabilitas. (Bandung : PT Remaja Rosdakarya, 2004. 
G. Zikmund William and Michael D'Amico. Marketing. Los Angeles : Printwise, 2000.

Ghozali Imam. Analisis Multivariate.

Semarang : Badan Penerbit Undip, 2005

Hasan Ali. Marketing. Yogyakarta : Media Pressindo, 2008.

Helmud P. Simanjuntak, Pengaruh Kualitas Layanan Faktor Manusia dan Kualitas Sarana serta Prasarana Terhadap Kepuasan Mahasiswa di Akademi Kimia Analis Bogor. Bogor : Tesis Program Pasca Sarjana Magister Manajemen Universitas Pakuan, 2009.

Iim Rohimah, Pengaruh Kualitas Produk dan Fasilitas Pelayanan Terhadap Kepuasan Pelanggan di Kantor Cabang Perum Pegadaian Bogor, (Bogor : Tesis Program Pasca Sarjana Magister Manajemen Universitas Ibn Khaldun, 2010)

James A. F. Stoner, R. Edwar Freeman and Daniel R. Gilbert, JR. Management. America : Prentice Hall, 2000.

Kotler Philip. Marketing in the Public Sector. America : Pearson Education, 2007.

Marketing Management. Mexico : Prentice Hall, 2000. - Manajemen Pemasaran. Jakarta : PT. Prenhallindo, 2002.

Kotler Philip dan Gary Amstrong. Dasar-dasar Pemasaran. Jakarta : PT. Indeks, 2004.

Kotler Philip dan Kevin Lane Keller. Manajemen Pemasaran. Jakarta : PT. Indeks, 2007.

Lovelock Christopher and Lauren Wright. Principles of Service Marketing and Management. Machfoedz Mahmud. Komunikasi Dengan Konsumen. Yogyakarta : Cakra Ilmu, 2010.
Malhotra, Naresh K. Marketing Reserch $\therefore$ An Apllied Oriention. $4^{\text {th }}$ Edition. New Jersey : Pretince Hall International, Inc, 2004

McCarthy E. Jerome and William D. Perreault. Essentials of Marketing. Sydney : Irwin,2000.

Subagyo Ahmad. Marketing in Business. Jakarta : Mitra Wacana Media, 2010.

Sugiyono. Metode Penelitian Pendidikan. Bandung : CV. Alfabeta, 2010 . Metode Penelitian Kuantitatif, Kualitatif, dan Kombinasi. Bandung: CV. Alfabeta, 2011)

Supriadi Setiawan. Loyalitas Pelanggan Jasa. Bogor : PT Penerbit IPB, 2011.

Sunarto. Manajemen Pemasaran 2. Yogyakarta : Aditya Media, 2006.

Tjiptono Fandy. Strategi Kepuasan Pelanggan. Yogyakarta : CV. Andi Offset, 2008

Tjiptono Fandy, Gregorius Chandra, dan Dedi Adriana. Pemasaran Strategik. Yograkarta : CV. Andi Offset, 2008. 